\title{
Key Factors for Determining Students' Satisfaction in Distance Learning Courses: A Study of Allama Iqbal Open University
}

\author{
Afzaal Ali \\ Israr Ahmad \\ International Islamic University, Pakistan
}

\begin{abstract}
Most of the people in Pakistan perceive distance learning as of poor quality. Therefore, the researchers conducted this study to find out whether it's only people's perception or is there anything in reality, concerning the poor performance of the distance learning students compared to traditional students. Consistent with this rationale, the main purpose of this study was to examine the relationship between student satisfaction and the following variables of the distance learning environment: Instructors' performance, course evaluation, and student-instructor interaction. The sample consisted of 245 students of Allama Iqbal Open University of Pakistan. Keeping in view the nature of relationships among the variables, correlation matrix and regression analysis in addition to frequency analysis were used to analyze the findings. The results showed that just like in traditional education, in distance learning at AIOU, enough interaction takes place between students and instructors; courses are up to date and well-designed; instructors are devoted, motivated, and equipped with the required competencies. Moreover, the faculty at AIOU is delivering distance courses that meet students' needs with regard to student-instructor interaction, instructor performance, and course evaluation.
\end{abstract}

Key words: Distance learning; Student satisfaction; Instructor performance; Student-instructor interaction; Course evaluation

\section{Introduction}

In recent years, the growth of online educational programs has been fueled by the advancement of the internet and modern information technology that changed the face of education (Sher, 2008). The World Wide Web (www) has become a valuable educational means and offers new educational experiences for students, which were not earlier possible. Due to the advancement of the latest technology, online education has emerged as an alternative or at least a considerable supplement to traditional mode of teaching and learning (Waits \& Lewis, 2004). Especially in higher education, online education is increasingly becoming common and emerging as an opportunity for delivering entire education online (Johnson, 2004). In academia, through online classes, universities now have the ability to provide distance learning opportunities for students--full-time or part-time, traditional or non-traditional and international or local, who perhaps have had limited access to advanced educational opportunities (Bartley et al., 2004). 
The rising demand and growing consumer experience with flexible education programs to support career development and lifelong learning has increased people's expectations for quality instruction, effective educational outcome, and finally satisfaction for learning (Debourgh, 1999). Allen et al. (2002) and Wang (2003) argued that in any educational institution, the satisfaction of a student can be determined from his level of pleasure as well as the effectiveness of the education that the student experiences. Students with higher levels of satisfaction towards various aspects of e-learning courses are reported to show considerably higher levels of learning than students with low level of satisfaction (Fredericksen, 2000). In this regard, specifically instructors of e-learning courses can increase their students' satisfaction by considering the primary factors of student satisfaction (Ho et al., 2002).

No doubt, new telecommunications hardware and software provide many opportunities of communication and collaboration for students and instructors, separated from each other due to time difference and space (Belanger \& Jordan, 2000). However, besides a perception of the technological innovation, interaction among students, as well as quality and timely interaction between the student and the teacher, flexibility of online courses, availability of technical support, and consistent instructional design across courses are also important to assure the development of distance education (Lao \& Gonzales, 2005; Swan et al., 2000; Young \& Norgard, 2006).

Conrad (2006) argued that distance learning occurs when students and instructor do not meet personally in the same physical space. Similarly, Roffe (2002) described that distance learning refers to the way people communicate and learn by electronic means, which has emerged as a key source of competitive advantage in the information society. The term distance learning is also used interchangeably with terms like e-learning, online learning, online collaborative learning, virtual learning, web-based learning and technology-mediated learning. In the past, few relevant studies have been conducted on the use of distance learning environment in Pakistan. Therefore, this current research study deals with several factors which have influenced students' satisfaction with distance learning in Pakistan. In this perspective, the primary objective of this research study was to examine the relationship between student satisfaction and the following variables of the distance learning environment: Instructors' performance, course evaluation and student-instructor interaction.

Actually, this study was conducted to address the most recent problems of AIOU students, relevant to their distance learning experiences. The fact is that most of the people in Pakistan perceived distance learning as of poor quality. Entrepreneurs, private employers and many corporate executives have almost the same perception. Moreover, they are not ready to accept the argument that distance learning students do just or even better than face to face classroom students. Despite the fact that the AIOU degree is accepted and recognized by the government, getting jobs, particularly good jobs are very difficult for these students. Therefore, the researchers conducted this study to find out whether it's only people's perception or is there any evidence in reality about the poor performance of the distance learning students as compared to traditional students. That's why we posed various questions to AIOU students about their individual satisfaction regarding instructor performance, student-instructor interaction, and general course evaluation. 
Secondly, this study was carried out by keeping in view the increasing demand for distance education not only in Pakistan but all over the world. Right now there is only one degree awarding university in Pakistan providing distance education (Allama Iqbal Open University - AIOU). Thus, we focused on AIOU in this study.

The AIOU was established in May 1974 in Islamabad, Pakistan and was the first Open University in Asia, and the biggest university in the country with course enrolment of 1,806,214 by the year 2004-2005. The AIOU established over 1400 study centers, 9 regional campuses, 23 regional centers, 90 part-time regional coordinating offices throughout Pakistan. Basically, AIOU is a distance education institution, which provides multidisciplinary education from basic to doctoral level programs. In AIOU more than 70 percent of students are employed and the rural-urban distribution of the students is $58 \%$ and $42 \%$ respectively. Moreover, female enrolments are more than 50 percent. The Internet, audio and video lectures along with correspondence with the instructors are used as a medium of instruction as well as a source of information. In addition, these lectures are broadcasted on television and radio; CDs of these lectures are also available for the students.

\section{Literature Review}

\section{Student Satisfaction}

The dynamic expansion of online teaching and learning has been boosted significantly by the rapid development of the internet and various web resources, having a tremendous impact on the quality of teaching and learning (Kramer, 2000). Zaidel (2007) added that the use of information technology becomes well-known in education. Modernized way of communication came into being, which change the preference of students from face-to-face to online education. Furthermore, the availability of distance education, the course offerings, and the increasing number of students enrolled, all speak to the importance of this method of instruction (Zapalska \& Brozik, 2006).

Brownson and Harriman, (2000) argued that students in distance learning do just or even better than face to face classroom students. Besides, Johnson et al. (2000) made a comparative research study and did not find any significant difference in the effectiveness of online learning versus face to face course learning for students.

Furthermore, distance education provides independent, student-centered and tutor-guided engagement that facilitates interactions with instructors and students which may not always be possible within the traditional classroom setting (Michailidou \& Economides, 2003). Astin, (1993) defined student satisfaction in term of student's perception towards his/her college or university experience, and perceived significance of the education that (s)he received from an institution. Levy (2003) concluded in his research study, which was conducted over 200 students attending elearning courses, that students' satisfaction with e-learning is an important factor to measure the effectiveness of e-learning. 


\section{Instructor Performance and Student Satisfaction}

In an online learning environment, the instructor is required of a new set of skills for success since latest technologies brings as much change to instructors as they do to students (Jones, 2003). Now, the roles of the instructors change from being the primary source of students' knowledge to being the manager of the students' knowledge resources (Romiszowski, 2004). Moreover, in an effective online learning environment, instructor plays a central role. It is not only because of technology but practical accomplishment of the technology that has certain effects on learning (Collis, 1995).

An instructor has a definite role to make the online environment successful. For this purpose, instructors must ensure required level of interactions and discussions with their students (Hong et al., 2003). However, interaction is different in this environment (Walker \& Hackman, 1991) with more emphasis on the instructor's role as a mediator between the student and the materials (Beaudoin, 1990) or between the student and the technology (Hillman et al., 1994). Therefore, instructor must understand the increased diversity of learners, and then accordingly determine test formats, measurement practices, and assessment strategies (Banerjee \& Brinckerhoff, 2002), which might persuade and motivate students to accept e-learning environment (Selim, 2005).

In e-learning, there are certain factors and conditions, which are closely related to the professional development of an instructor, and to enhance the teaching quality of instructors, it is necessary for the instructors to consider these factors (Louden, 2000). Jensen (1993) conducted a study in which he collected data from students and instructors, and concluded that distance education requires a different set of skills and involves different responsibilities.

\section{Student-Instructor Interaction and Student Satisfaction}

In distance education practices, interaction often appears as a defining characteristic of quality learning experiences. Also, in the education literature, researchers' belief in the importance of student-teacher interaction is so widespread that it is assumed to be a basic need for learning to occur (Anderson \& Garrison, 1995; Picciano, 2002). In addition, it is recognized as a driving force for persuading student's motivation and the achievement of learning outcomes (Du, Havard, \& Li, 2005; Lam, Cheng, \& McNaught, 2005; Sargeant, Curran, Allen, Jarvis-Selinger, \& Ho, 2006; Tu, 2005). Moore (1989) reported three types of interactions: Student-content; student-instructor; and student-student. Young and Norgard (2006) also confirmed the importance of these three types of interactions for student satisfaction with distance education; timely and quality interaction among students and between student and their instructor, and finally between students and their course content.

According to many researchers, the overall effectiveness and success of online education depends upon the interaction which is an essential element to a student learning (Fresen, 2007; Moore, 1993; Northrup, 2001). Therefore, Volery et al. (2000) suggested that in order to boost student's interactions, the instructor may give a participation mark. Furthermore, instructors should be able to understand the diverse nature of students, involve them in online discussions and encourage student to student interactions (Durling, Cross, \& Johnson, 1996). 
In an online course, the immediate accessibility of the information, assistance, and feedback by the instructor determine the students' satisfaction. Whenever, due to technical problems, this accessibility is interrupted or denied, students get frustrated (Wilson \& Whitelock, 1998). In fact, success in an online learning environment depends on the level of interaction between students and instructors that is required to stimulate good results (Kershaw, 1996). Due to an online learning environment, the instructor gets more time to directly interact and spend on each individual student so that most students follow a pre-defined and pre-developed e-learning course (Morgan, 2000). Therefore, instructors should remain in contact with students through e-mail and online forum discussions (Poon et al., 2004)

\section{Course Evaluation and Student Satisfaction}

The development of an online environment allows students to participate in the educational process by exploring and playing with the lesson material (Michailidou \& Economides, 2003). Particularly the subjects that involve discussion, brainstorming, and reflection are best suited to the online format (Wells, 1992). Students' interactions through course discussions appear to be one of the most important features of distance courses (Swan, Shea, Fredericksen, Pickett, Pelz, \& Maher, 2000). Along with this, course design must have rich communication potential, as the level of communication has a clear impact upon students' learning, satisfaction, and retention in online courses (Irani, 1998).

Northrup (2002) defined interaction as interaction with a course content, discussion and group effort, interpersonal skills, and need for support. Furthermore, Northrup added that students demonstrated a preference for innovative course delivery such as collaboration through ongoing interaction with peers and instructors, case studies, readings followed by discussions. According to Inman et al. (1999), students expect three things from an instructor in the distance learning environment, which are helpful materials for interacting with the distance learning medium, some on-campus session and finally his availability at the time when they need. Besides, Swan (2001) reported three factors such as interaction with instructors and active discussion among course participants and clarity of course design, which significantly influenced students' satisfaction and perceived learning. Similarly, Shea, Pickett, and Pelz (2003) argued that following issues are highly correlated with students' satisfaction level in e-learning courses: Instructional design and organization of the e-learning courses, instructors' direct interaction with students, and instructors discourse facilitation.

According to Levin et al. (1990), students perceive that discussions in distance learning are more equitable and democratic than face-to-face classroom discussions. While Swan et al. (2000) argued that students preferred consistent course structure so that navigation does not change from one course to another. Yang and Cornelius (2004) found that students became frustrated when their courses were poorly designed, and when instructors did not participate in discussions or responded to questions within a very limited time (Zeng \& Perris, 2004). There may be a possibility that this frustration may translate into a poor learning outcome for students. Therefore, in online learning environment, getting student feedback about their needs and preferences is crucial for the successful design and implementation of this environment (Sahin, 2007). 


\section{Theoretical Framework}

The following conceptual model is proposed on the basis of the literature review and theoretical background (Figure 1).

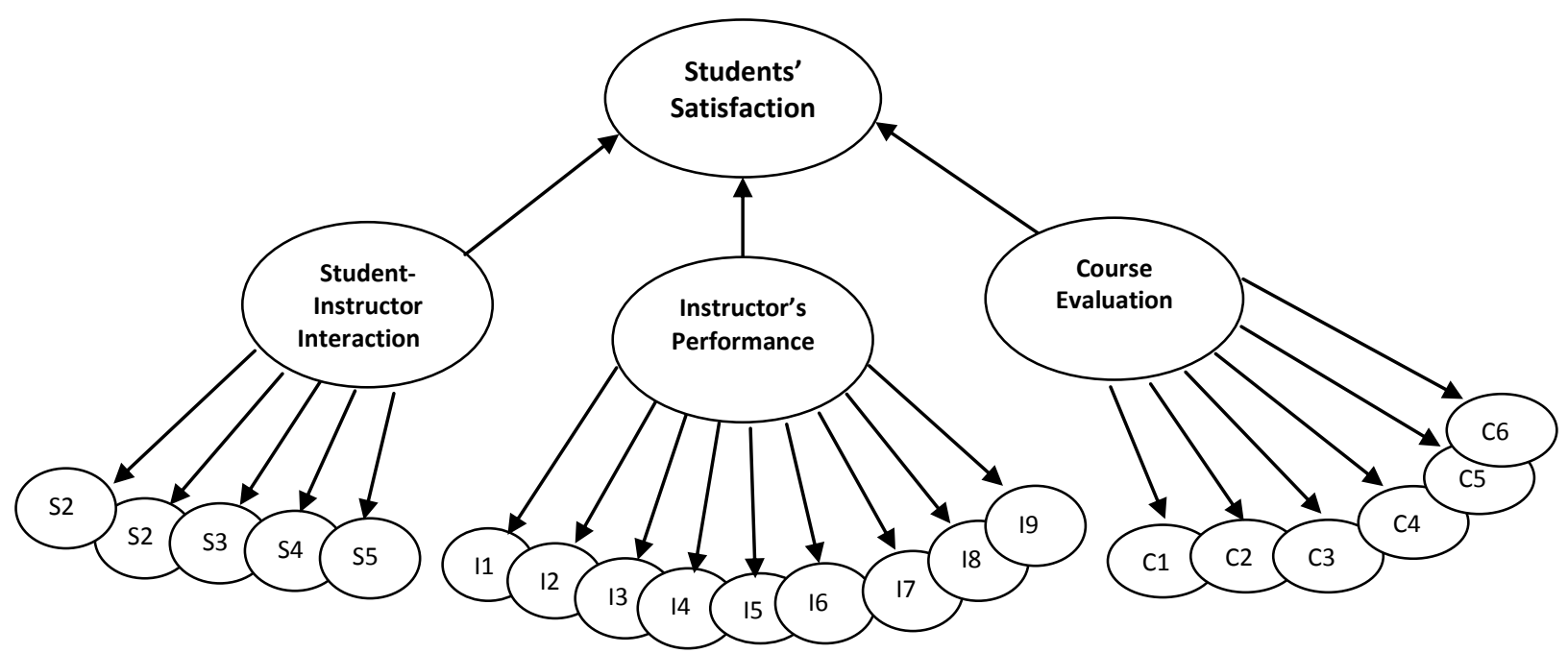

Where " $S$ " stand for "Student-Instructor Interaction", "I" stand for "Instructor's Performance" and "C" stand for "Course Evaluation"

\section{Research Hypotheses}

The following hypotheses have been developed from the literature review:

H1: Instructor performance will be positively related to the student's satisfaction.

H2: $\quad$ Student-instructor interaction will be positively related to the student's satisfaction.

H3: $\quad$ Course evaluation will be positively related to the student's satisfaction.

\section{Methodology}

In order to investigate the relationship among key factors for determining students' satisfaction in distance learning courses, a structured questionnaire was circulated among students of AIOU in Pakistan, using convenience sampling method. There were various survey techniques which could be used for the collection of data, such as telephone interviews, face to face interviews, the internet or self-administered questionnaire etc. Of course, every technique has its own advantages and disadvantages. We preferred and employed a self-administered questionnaire to collect data from the respondents in this study because we thought that it would address the overall research objectives and hypothesis better. 
As AIOU is the only university which provides distance learning education in Pakistan, it was the obvious choice for the researchers. The sample comprised of 245 students of AIOU. The research team made a visit to AIOU main campus in Islamabad and collected data from the students. For this purpose, the researchers first briefed them about the purpose of this study and the variables along with their items, which were in the questionnaire. The questionnaire consisted of 26 items. It had two parts. The first part contained demographic information and the second part contained the variables and their related items. The demographic profile included four items: Gender, age, student type, and academic program.

\section{Measures/Instruments}

To address the research question stated in the study, all measures for the constructs were taken from previous studies, which were carried out from education perspective due to their proved reliability and validity.

\section{Student Satisfaction}

To measure the students' satisfaction, six items were adapted from the study of Arbaugh (2000). These items focus on students' satisfaction, their perceptions of its quality and their intention of taking future courses via distance learning. Each item was measured on five-point Likert scale with response options ranging from strongly disagree (1) to strongly agree (5). The mean and standard deviation of the scale was found to be normal and acceptable for the purpose of statistical analysis $(M=3.65, S D=0.676)$.

\section{Student-Instructor Interaction}

Similarly, for measuring the variable of student-instructor interaction, researchers used items of Johnson et al. (2000). Each item was measured on five-point Likert scale with response options ranging from strongly disagree (1) to strongly agree (5). The mean and standar deviation of the scale was found to be normal and acceptable for the purpose of statistical analysis $(M=3.74, S D=$ 0.553).

\section{Instructor Performance and Course Evaluation}

Likewise, the Teaching Evaluation Scale items (Fall 2001) of the College of Education at Texas Tech University were used to measure instructor performance and course evaluation (Tallent-Runnels et al., 2005). Each item was measured on five-point Likert scale with response options ranging from strongly disagree (1) to strongly agree (5). The mean and standar deviation of the scales were found to be normal and acceptable for the purpose of statistical analysis $(M=3.66, S D=0.643 ; M=$ $3.79, \mathrm{SD}=0.531$ ) respectively. 


\section{Sample Characteristics}

Table 1 shows the demographic profile of the students'. According to this table, Male students comprised about $53 \%$, while Female students constituted $47 \%$ of the sample. The profile of the students discloses that out of 245, $168(69 \%)$ students were between 20 to 25 years of age, whereas 77 (31\%) were above 25 years of age. Furthermore, out of 245 students, 156 (64\%) were studying as part time students, whereas 89 (36\%) were full time students.

Table 1. Demographics of the Sample

\begin{tabular}{|c|c|c|}
\hline & $\mathbf{N}$ & $\%$ \\
\hline \multicolumn{3}{|l|}{ Gender } \\
\hline Male & 131 & 53 \\
\hline Female & 114 & 47 \\
\hline \multicolumn{3}{|l|}{ Age } \\
\hline Between 20 to 25 & 168 & 69 \\
\hline Above 25 & 77 & 31 \\
\hline \multicolumn{3}{|l|}{ Students' type } \\
\hline Part time & 156 & 64 \\
\hline Full time & 89 & 36 \\
\hline \multicolumn{3}{|l|}{ Academic Program } \\
\hline Intermediate & 18 & 7 \\
\hline Bachelor & 48 & 20 \\
\hline Master & 167 & 68 \\
\hline Others & 12 & 5 \\
\hline
\end{tabular}

Researchers divided academic programs into four categories/levels as intermediate, bachelor, master, and other. As seen from the table, 18 (7\%) students were in intermediate, $48(20 \%)$ students were in bachelor's, 167 (68\%) students were in master's, and 12 (5\%) students were in other programs.

From these figures, it can be said that students in the sample were distributed closely with regard to gender (about fifty percent each). However, approximately two thirds of them were younger than 25 years old, part time students, and in master's programs.

\section{Analysis and Results}

\section{Reliability Analysis}

Prior to actual data collection, the reliability coefficient alpha was used to measure the reliability of the constructs in the pilot study. The sample for the pilot study comprised of 23 respondents. Table 2 shows the items and Cronbach's alpha coefficient for each variable respectively, which are all at acceptable levels. 
Table 2. Means, Standard Deviations and Cronbach Alphas

\begin{tabular}{llcccc}
\hline Construct & $\begin{array}{c}\text { No of } \\
\text { Items }\end{array}$ & Mean & Std. Deviation & $\begin{array}{c}\text { Cronbach } \\
\text { Alpha }\end{array}$ \\
\hline 1. & Students' satisfaction & 6 & 3.65 & 0.676 & 0.680 \\
2. Student-instructor interaction & 5 & 3.74 & 0.553 & 0.737 \\
3. Instructor's performance & 9 & 3.66 & 0.643 & 0.882 \\
4. & Course evaluation & 6 & 3.79 & 0.531 & 0.680 \\
\hline
\end{tabular}

\section{Descriptive Analysis}

Table 2 presents the mean values of the variables. The mean value of all the variables is greater than 3.5. The higher mean values of "Students' satisfaction", "Student-instructor interaction", "Instructor's performance", and "Course evaluation" indicate good practices of the distance learning degree programs by the AIOU, which yield students satisfaction and effective learning environment.

\section{Test of Hypotheses}

To investigate the relationship between the dependent variable, student satisfaction, and the following three predictor variables were tested: Student-instructor interaction, instructor performance, and course evaluation; the data were subjected to regression and correlation analysis. The results are shown in Table 3 which clearly demonstrates that there is significant relationship between the independent variables and the dependent variable.

Table 3. Students' Satisfaction

\begin{tabular}{lll}
\hline Student-instructor interaction & Pearson Correlation & $0.413^{* *}$ \\
& Sig. (2-tailed) & .000 \\
& $\mathrm{~N}$ & 245 \\
Instructor's performance & Pearson Correlation & $0.616^{* *}$ \\
& Sig. (2-tailed) & .000 \\
& $\mathrm{~N}$ & 245 \\
Course evaluation & Pearson Correlation & $0.637^{* *}$ \\
& Sig. (2-tailed) & .000 \\
& $\mathrm{~N}$ & 245 \\
& & \\
\hline
\end{tabular}


The correlation matrix (Table 3 ) indicates that student-instructor interaction is positively and significantly correlated with students' satisfaction [ $r=0.413, p<0.05, \mathrm{H} 1$ supported]. The results reveal that instructor performance positively and significantly influence the students' satisfaction $[\mathrm{r}=0.616, \mathrm{p}<0.05, \mathrm{H} 2$ supported]. Likewise, there is also a significant and positive relationship between the course evaluation and students satisfaction [ $r=0.637, p<0.05, \mathrm{H} 3$ supported].

Table 4. Results of Regression Analysis (Dependent variable = Students' satisfaction)

\begin{tabular}{llccc}
\hline Hypothesis & \multicolumn{1}{c}{ Description } & $\begin{array}{c}\text { Path Coefficient } \\
(\boldsymbol{\beta})\end{array}$ & t-value & p-value \\
\hline $\mathrm{H}: 1$ & Student-instructor interaction & .583 & 6.590 & .000 \\
$\mathrm{H}: 2$ & Instructor's performance & .721 & 7.660 & .000 \\
$\mathrm{H}: 3$ & Course evaluation & .510 & 7.068 & .000 \\
\hline $\mathrm{n}=245 ;$ & R Square $=.528 ;$ & Adjusted R Square $=0.522 ; \mathrm{F}=89.897 ;$ Significance $\mathrm{p}<0.001$ \\
\hline
\end{tabular}

Results of regression analysis in Table 4 show that overall the full model, with three independent variables and one dependent variable was highly powerful with an overall $F=89.897(p<0.001)$. Moreover, this explained $52 \%$ of the variation in the dependent variable as indicated by the adjusted $\mathrm{R}^{2}$ value. According to the results of regression analysis, all of three hypotheses were accepted.

The results in Table 4 demonstrate that $58 \%$ of variation in the dependent variable (student satisfaction) is caused by the independent variable of student-instructor interaction. This suggests that results are significant and hence $\mathrm{H} 1$ is accepted $(p<.05, t=6.590)$.

Similarly, the results in Table 4 illustrate that $72 \%$ of variation in dependent variable (student satisfaction) is caused by the independent variable of instructor performance. This suggests that results are significant and hence $\mathrm{H} 2$ is accepted $(p<.05, t=7.660)$.

The results in Table 4 also indicate that $51 \%$ variation in dependent variable (student satisfaction) is caused by the independent variable of course evaluation. This again follows the same pattern in other independent variables and suggests that results are significant so that $\mathrm{H} 3$ is accepted $(p<.05$, $\mathrm{t}=7.068$ ).

\section{Discussions}

Percentage distributions for the items and subcategories of the survey are depicted in Table 5. It appears that the most preferred options for responses are either "Agree" or "Strongly Agree." This in general shows that respondents were positive in their evaluations of the dimensions of distance education practices at AIOU. 
Table 5. Key Factors for Determining Students' Satisfaction

\begin{tabular}{|c|c|c|c|c|c|}
\hline Student-Instructor Interaction & SD\% & D\% & N\% & A\% & SA\% \\
\hline $\begin{array}{l}\text { The instructors encouraged me to become actively involved in the } \\
\text { courses discussions }\end{array}$ & 17.6 & 11.4 & 2.4 & 37.6 & 31.0 \\
\hline The instructors provided me feedback on my work through comments & 7.3 & 12.7 & 7.8 & 20.8 & 51.4 \\
\hline I was able to interact with the instructors during the courses discussions & 5.3 & 9.8 & 9.8 & 33.5 & 41.6 \\
\hline The instructors treated me individually & 5.3 & 18.4 & 26.1 & 23.3 & 26.9 \\
\hline The instructors informed me about my progress periodically & 14.7 & 13.5 & 19.2 & 35.1 & 17.6 \\
\hline Instructor's Performance & SD\% & $\mathbf{D} \%$ & N\% & A\% & SA\% \\
\hline Overall this instructors were effective & 2.4 & 12.7 & 12.7 & 33.5 & 38.8 \\
\hline $\begin{array}{l}\text { The instructors were available for consultation during office hours or by } \\
\text { appointment. }\end{array}$ & 4.9 & 18.8 & 15.5 & 29.4 & 31.4 \\
\hline The instructors stimulated students learning. & 0 & 12.2 & 10.2 & 21.6 & 55.9 \\
\hline The instructors treated all students fairly & 9.0 & 15.1 & 21.6 & 22.4 & 31.8 \\
\hline The instructor treated all students with respect & 4.9 & 6.5 & 9.8 & 43.7 & 35.1 \\
\hline The instructor welcomed and encouraged questions and comments. & 4.9 & 14.3 & 2.9 & 34.7 & 43.3 \\
\hline The instructor presented the information clearly. & 2.4 & 23.7 & 7.8 & 39.2 & 26.9 \\
\hline The instructor emphasized the major points and concepts. & 11.8 & 7.3 & 9.8 & 29.4 & 41.6 \\
\hline The instructor demonstrated knowledge of the subject. & 2.4 & 23.7 & 7.8 & 39.2 & 26.9 \\
\hline Course Evaluation & SD\% & D\% & N\% & A\% & SA\% \\
\hline Overall, I have valuable learning experiences from my courses. & 4.9 & 2.4 & 4.5 & 33.9 & 54.3 \\
\hline The assignments were relevant and useful. & 9.0 & 2.4 & 7.3 & 53.5 & 27.8 \\
\hline Courses materials were relevant and useful & 2.4 & 9.8 & 4.9 & 38.4 & 44.5 \\
\hline Expectations were clearly stated either verbally or in the syllabus. & 12.7 & 7.3 & 4.5 & 47.8 & 27.8 \\
\hline The testing and evaluation procedures were fair. & 16.7 & 9.8 & 4.9 & 51.0 & 17.6 \\
\hline The workload was appropriate for the hours of credit. & 7.8 & 14.7 & 18.4 & 44.5 & 14.7 \\
\hline
\end{tabular}

\section{Student-Instructor Interaction}

Student-Instructor Interaction is the first strongest variable in predicting students' satisfaction. Students were asked about their course discussions, feedback and interaction with instructors, instructors' ability to treat them individually and lastly informing them about their progress periodically. Approximately, $68 \%$ of the students agreed that instructors encouraged them to become actively involved in the course discussions. The student comments support the need for instructor's encouragement to actively involve students in the course discussions. These were substantiated by the findings of Durling et al. (1996). 
Furthermore, the majority of the students, $71 \%$ and $75 \%$ reported they liked discussion and feedback from their instructors. Although, almost $51 \%$ of the respondents agreed that instructors treated them individually and also informed them about their progress periodically, on average $26 \%$ disagreed with these statements. As distance education is a learner-centered instruction, this finding confirms that instructor support, such as useful feedback, easy communication and timely help are still important factors for student satisfaction in distance learning. According to Young and Norgard (2006), timely interaction with students regarding their performance enhances their productivity in distance learning courses. Furthermore, in terms of achieving overall student satisfaction, distance learning instructors should be able to understand the diversity of the students and treat each student accordingly (Banerjee \& Brinckerhoff, 2002).

\section{Instructor's Performance}

The second significant predictor of student satisfaction is instructor performance. In this section students were asked whether "Overall these instructors had been effective". Approximately, 72\% of the students agreed that during their degree program, overall the instructors were effective. The student comments support the need for experienced professional instructors for the student's satisfaction (Hong et al., 2003). Moreover, students were asked about teachers' availability during office hours, their motivation to learn, giving them respect, encouraging question and comments, presenting the information clearly, highlighting the major points and concepts, and demonstration of knowledge. On average about $68 \%$ of the respondents agreed about all these points and considered these things important in order to enhance their satisfaction with distance learning courses.

Therefore, instructors of distance education should be available, provide prompt responses, and encourage their students through online learning activities. These findings also suggest that interaction with the instructor in distance learning environment affects student success and learning (Areti, 2006; Chen \& Guo, 2005).

\section{Course Evaluation}

Students were queried about their feelings regarding learning experiences, assignments, course materials, achievement of course targets, workload and evaluation criteria in their distance courses. According to Table 5, a majority of the students agreed that they learned a lot from their courses and assignments, and that courses materials were relevant and useful, that course objectives were achieved during the semester, and that evaluation criteria as well as workloads were satisfactory. These findings indicate that students are expected to be more satisfied in distance learning environments if the course materials are relevant and useful, and involve real life examples, facts, and cases (Northrup, 2002).

Moreover, the characteristics of course content also contributes to distance learning satisfaction. Students view distance learning course content such as audio and video lectures that is intended to be for supplementary use, differently from core course content which is in the form of books and assignments. They expect e-learning content to be clearly presented in a lively format such as 
a web page which summarizes course content, web links to other learning resources, practical "real-world" examples, or a site where they can practice specific skills.

\section{Conclusions and Implications}

This study investigated how students' satisfaction could be measured in distance learning. The distance learning in this study refers to the use of the Internet, audio and video lectures along with correspondence of the instructors as a medium of instruction as well as a source of information. Part time/full-time, undergraduate and graduate students studying in AIOU main campus were selected as the sample for this study. The results confirm the reliability and validity of the three dimensions of distance learning satisfaction, which are student-instructor interaction, instructor's performance, and course evaluation. These dimensions can be understood as the way the course content is delivered, feedback and interactions take place with instructors, effectiveness of instructors, students learning experiences, workload and evaluation criteria in their distance courses, and convenience of the means of communication, the ease of system operation for the learners, and the quality of content the students receive.

The results of this study further indicated that the majority of the students at this campus showed high levels of satisfaction regarding student-instructor interaction, instructor's performance and course evaluation. This reveals that just like in traditional education, in distance learning education at $\mathrm{AIOU}$, enough interaction takes place between students and their instructors, courses are up to date and well designed, instructors are devoted, motivated and equipped with the required skill and knowledge. Furthermore, the availability of distance education in Pakistan, increasing number of degree programs offered and the increasing number of students enrolled, all speak for students' satisfaction and the effectiveness of distance learning education. This implies that the faculty at AIOU is delivering distance learning courses that meet the students' needs in regard to students-instructor interaction, instructor performance, and course evaluation.

After the findings of this research study, it would not be logical to presume that distance learning students do not perform as well as traditional students. Moreover, the research team hopes that these findings may change the pessimistic perceptions of those people in Pakistan, who perceived distance learning as poor in quality.

Besides, there appears to be a need for AIOU to increase the number of its sub-campuses to remote areas of Pakistan where the literacy rate is still low. It is important to recognize that students of these areas have strong desire to get education but due to financial, geographic and cultural reasons they cannot get it. Therefore, virtual university can play a vital role in improving the literacy rate in Pakistan.

\section{Limitations and Future Research Direction}

There are certain limitations of this study. The relatively small sample size may not be completely representative of the majority of students of distance learning programs at AIOU. Additionally, the 
main campus of AIOU in Islamabad was selected but his may not reflect the results of the whole AIOU campuses.

For future point of view, one can consider the students of other campuses and subcampuses of AIOU, especially those established in small and underdeveloped cities in order to find out their satisfaction levels toward distance learning. Secondly, to explore the reasons why students select distance learning for higher education in Pakistan is also an important issue for future research studies.

\section{References}

Allen, M., Bourhis, J., Burrell, N., \& Mabry, E. (2002). Comparing student satisfaction with distance education to traditional classrooms in higher education: A meta-analysis. American Journal of Distance Education, 16(2), 83-97.

Anderson, T. D. \& Garrison, D. R. (1995). Transactional issues in distance education: The impact of design in audio teleconferencing. The American Journal of Distance Education, 9, 27-45.

Arbaugh, J.B. (2000a). Virtual classroom characteristics and student satisfaction with Internetbased MBA courses. Journal of Management Education, 24, 32-54.

Astin, A. W. (1993). What matters in college? Four critical years revisited. San Francisco, CA: Jossey-Bass.

Banerjee, M. \& Brinckerhoff, L. C. (2002). Assessing student performance in distance education courses: Implications for testing accommodations for students with learning disabilities. Assessment for Effective Intervention, 27(3), 25-35.

Bartley, S. J. \& Golek, J. H. (2004). Evaluating the cost effectiveness of online and face-to-face instruction. Educational Technology \& Society, 7(4), 167-175.

Beaudoin, M. (1990). The instructor's changing role in distance education. The American Journal of Distance Education, 4(2), 26-34.

Belanger, F. \& Jordan, D. H. (2000). Evaluation and implementation of distance learning: Technologies, tools and techniques. Hershey, PA: Idea.

Collis, B. (1995). Anticipating the impact of multimedia in education: Lessons from the literature. Computers in Adult Education and Training, 2(2), 136-49.

Conrad, D. (2006). E-learning and social change: An apparent contradiction. In M. Beaudoin (Ed.), Perspectives on higher education in the digital age (pp.21-33). New York: Nova.

DeBourgh, G. A. (1999). Technology is the tool, teaching is the task: Student satisfaction in distance learning. Proceedings of Society for Information Technology and Teacher Education International Conference (pp.131-137).

Du, J., Havard, B., \& Li, H. (2005). Dynamic online discussion: Task-oriented interaction for deep learning. Educational Media International, 42(3), 207-218.

Durling, D., Cross, N., \& Johnson, J. (1996, June). CAl with style. Paper presented at the 18th Annual Design Conference-Computer-aided Design Education. University of Bristol, England. 
Fredericksen, E., Pickett, A., Shea, P., Pelz, W., \& Swan, K. (2000). Student satisfaction and perceived learning with on-line courses: principles and examples from the SUNY learning network. Journal of Asynchronous Learning Networks, 4(2), 7-41.

Fresen, J. (2007). A taxonomy of factors to promote quality web-supported learning. International Journal on E-Learning, 6(3), 351-362.

Ho, C., Leong, P., \& Saromines-Ganne, B. (2002). An empirical investigation of student satisfaction with Web-based courses. In M. Driscoll \& T. Reeves (Eds.), Proceedings of World Conference on E-Learning in Corporate, Government, Healthcare, and Higher Education (pp. 1792-1795).

Hong, K.S., Lai, K.W., \& Holton, D. (2003). Students' satisfaction and perceived learning with a Web based course. Journal of Educational Technology \& Society, 6(1), 116-124.

Inman, E. , Kerwin, M., \& Mayes, L. (1999). Instructor and student attitudes toward distance learning. Community College Journal of Research and Practice, 23(6), 581-591.

Irani, T. (1998). Communication potential, information richness and attitude: A study of computer mediated communication in the ALN classroom. ALN Magazine, 2 (1) [Online].

Jensen, R. E. (1993). The technology of the future is already here. Academe, 79, 8-13.

Johnson, S. D., Aragon, S. R., Shaik, N., \& Palma-Rivas, N. (2000). Comparative analysis of learner satisfaction and learning outcomes in online and face-to-face learning environments. Journal of Interactive Learning Research, 11(1), 29-49.

Jones, A. J. (2003, January). ICT and Future Teachers: Are we preparing for e-Learning? Paper presented at the IFIP Working Groups 3.1 and 3.3 Conference: ICT and the Teacher of the Future. Melbourne, Australia. [Journal of Distance Education, 4, 21-29].

Kershaw, A. (1996). People, planning, and process: The acceptance of technological innovation in post-secondary organizations. Educational Technology, 36, 44-48.

King, K. P. (2002). Educational technology professional development as transformative learning opportunities. Computers \& Education, 39, 283-297.

Lam, P., Cheng, K. F., \& McNaught, C. (2005). Asynchronous online discussion: Empirical evidence on quantity and quality. Norfolk, VA: Association for the Advancement of Computers in Education.

Lao, T. \& Gonzales, C. (2005). Understanding online learning through a qualitative description of professors' and students' experiences. Journal of Technology and Teacher Education, 133, 459-474.

Levin, J. A., Kim, H. \& Riel, M. M. (1990). Analyzing instructional interactions on electronic message networks. In L. Harasim (Ed.), On-line education: Perspectives on a new environment (pp.1638). New York: Praeger.

Levy, Y. (2003). A study of learners perceived value and satisfaction for implied effectiveness of online learning systems. Dissertation Abstracts International, 65(03), 1014A.

Louden, W. (2000). Standards for standards: the development of Australian professional standards for teaching. Australian Journal of Education, 44(2), 118-34. 
Michailidou, A. \& Economides, A. (2003). E-learn: Towards a collaborative educational virtual environment. Journal of Information Technology Education, 2, 131-152.

Moore, M. G. (1989). Editorial: Three types of interaction, The American Journal of Distance Education, 3(2), 1-6.

Moore, M. G. (1993). Three types of interaction. In K. Harry, M. Hohn, \& D. Keegan (Ed.), Distance education: New perspectives (pp. 12-24). London: Routledge.

Morgan, B. (2000). Is distance learning worth it? Helping to determine the cost of online courses. ERIC Document Reproduction Service (ED446611).

Northrup, P. (2001). A framework for designing interactivity into Web-based Instruction. Educational Technology, 41(2), 31-39.

Northrup, P. T. (2002). Online learners' preferences for interaction. Quarterly Review of Distance Education, 32, 219-226.

Picciano, A. G. (2002). Beyond student perceptions: Issues of interaction, presence, and performance in an online course. Journal of Asynchronous Learning Networks, 6(1), 21-40.

Poon, W.C., Low, L.T., \& Yong, G. F. (2004). A study of Web-based learning (WBL) environment in Malaysia. The International Journal of Educational Management, 18(6), 374-385.

Roffe, I. (2002). E-learning: Engagement, enhancement and execution. Quality Assurance in Education, 10(1), 40-50.

Romiszowski, A. (2004). How's the e-learning baby? Factors leading to success or failure of an educational technology innovation. Educational Technology, 44(1), 5-27.

Sahin, I. (2007). Predicting student satisfaction in distance education and learning environments. Turkish Online Journal of Distance Education, 8(2), 1302-6488.

Sargeant, J., Curran, V., Allen, M., Jarvis-Selinger, S., \& Ho, K. (2006). Facilitating interpersonal interaction and learning online: Linking theory and practice. The Journal of Continuing Education in the Health Professions, 26, 128-136.

Selim, H. M. (2005). Critical success factors for e-learning acceptance: Confirmatory factor models. Computers and Education. Retrieved 9 February 2007, from http://mail.phy.bg.ac.yu/ $\sim$ marijam/ milos/science7.pdf.

Shea, P. J., Pickett, A. M., \& Pelz, W. E. (2003). A follow-up investigation of teaching presence in the SUNY learning network. Journal of Asynchronous Learning Networks, 7(2), 61-80.

Swan, K. (2001). Virtual interaction: Design factors affecting student satisfaction and perceived learning in asynchronous online courses. Distance Education, 22(2), 306-316.

Swan, K., Shea, P., Fredericksen, E., Pickett, A., Pelz,W., \& Maher, G. (2000). Building knowledge building communities: Consistency, contact and communication in the virtual classroom. Journal of Educational Computing Research, 234, 359-383.

Tallent-Runnels, T., Lan, M. K., Fryer, W. Y., Thomas, J. A., Cooper, T. S. \& Wang, K., (2005). The relationship between problems with technology and graduate students' evaluations of online teaching. Internet and Higher Education, 8, 167-174. 
Volery, T. \& Lord, D. (2000). Critical success factors in online education. The International Journal of Educational Management, 14(5), 216-223.

Vonderwell, S. (2003). An examination of asynchronous communication experiences and perspectives of students in an online course: A case study. The Internet and Higher Education, 6, 77-90.

Waits, T. \& Lewis, L. (2004). Distance education at degree granting postsecondary institutions: 2000-2001. Retrieved 19 November 2004 from http://nces.ed.gov/programs/quarterly/ vol_5/5_3/4_4.asp.

Walker, K. B. \& Hackman, M. Z. (1991). Information transfer and nonverbal immediacy as primary predictors of learning and satisfaction in the televised course. ERIC Document Reproduction Service (ED: 344266).

Wang, Y. S. (2003). Assessment of learner satisfaction with asynchronous electronic learning systems. Information and Management, 41(1), 75-86.

Wilson, T. \& Whitelock, D. (1998). Monitoring the on-line behavior of distance learning students. Journal of Computer Assisted Learning, 14, 91-99.

Yang, Y. \& Cornelius, L. F. (2004). Students' perceptions towards the quality of online education: A qualitative approach. Association for Educational Communications and Technology, 27, 861877.

Young, A. \& Norgard, C. (2006). Assessing the quality of online courses from the students' perspective. Internet and Higher Education, 9, 107-115.

Zeng, W. Y. \& Perris, K. (2004). Researching the efficacy of online learning: A collaborative effort amongst scholars in Asian open universities. Open Learning, 193, 247-264.

Correspondence: Afzaal Ali; Assistant Director; International Islamic University, Islamabad, Pakistan. 